\title{
Analisa Kapasitas Daya Dukung Cerocok Tunggal dan Kelompok Skala Lapangan
}

\author{
Sofyan ${ }^{(1)}$, Muhardi ${ }^{(2)}$, dan Ferry Fatnanta ${ }^{(3)}$ \\ Jurusan Teknik Sipil, Fakultas Teknik, Universitas Riau \\ Kampus Bina Widya Km 12,5, Simpang Baru, Pekanbaru 28293 \\ e-mail: sofyananis191@gmail.com
}

\begin{abstract}
Abstrak - Provinsi Riau didominasi oleh tanah lunak yang berupa tanah sedimen alluvial dataran rendah, terutama daerah rawa pasang surut di kabupaten yang dekat dengan sungai. Umumnya permasalahan yang timbul pada konstruksi di atas tanah lunak adalah besarnya penurunan dan kapasitas dukung yang rendah yang diakibatkan dari beban berat tanah itu sendiri. Penelitian dilakukan dengan pengujian di lapangan lokasinya di jalan sungai beringin kel. Sungai beringin Kab. Indragiri Hilir dengan variasi fondasi cerucuk bakau tunggal dan kelompok variasi spasi dengan panjang cerucuk yang di gunakan \pm 7 meter dengan metode loading test pemberian beban untuk cerucuk tunggal $50 \mathrm{~kg}(25 \%)$ hingga mencapai $200 \%$, untuk cerucuk Kelompok variasi spasi di beri beban $\pm 139 \mathrm{~kg}(25 \%)$ hingga beban mencapai $200 \%$.

Berdasarkan metode analis dan metode loading test yang digunakan. Dari hasil penelitian diperoleh cerucuk bakau group spasi 3 d memiliki kapasitas $Q$ ultimit yang besar dengan penurunan tanah yang kecil. Pengaruh variasi spasi dan konfigurasi cerucuk bakau terhadap kekuatan pengujian pembebanan cerucuk bakau juga memberikan nilai $Q$ ultimit yang berbeda. Variasi spasi dari hasil pengujian q ultimit pada cerucuk bakau di tanah lunak yang memiliki jarak (spasi 3 d) menghasilkan q ultimit lebih besar dibandingkan pemasangan cerucuk yang rapat $(0 \mathrm{~d})$, sedangkan variasi konfigurasi cerucuk bakau tunggal metode analis (metode Mayerhof) menghasilkan q ultimit $774,78 \mathrm{~kg}$ dan metode interpretasi (metode chin) sebesar $472 \mathrm{~kg}$
\end{abstract}

Kata Kunci : Pengaruh Spasi, Q ultimit, Analis, Interpretasi dan Cerucuk

\section{PENDAHULUAN}

Propinsi Riau merupakan wilayah yang memiliki lahan gambut yang terluas disumatra 4,044 juta ha $(56,1 \%$ dari luas lahan gambut Sumatra atau 45\% dari luas daratan Propinsi Riau). Kandungan karbon tanah gambut di Riau tergolong yang paling tinggi di seluruh Sumatera bahkan se-asia tenggara

Hutan alam yang tersisa di Propinsi Riau pada tahun 2007 seluas 2.478.734 Hektar, $65 \%$ di dominasi oleh hutan rawa gambut, sementara hutan dataran rendah kering yang tersisa hanya berada pada kawasan konservasi dan daerah yang sedang diperjuangkan untuk di konservasi. Disisi lain praktek-praktek pemanfaatan dan pengelolaan hutan alam dilapangan, saat ini tidak dapat menjamin hutan alam yang tersisa di Riau dapat dipertahankan

Kabuapten Indragiri Hilir sebagai Kabupaten yang mempunyai luasan gambut terbesar di Provinsi Riau, yaitu 982.524 hektar (Muslim dan Susanto Kurniawan , 2008). Seiring dengan pertumbuhan ekonomi di Kabupaten Indragiri Hilir, pembangunan gedung dan rumah tinggal juga cukup pesat. Namun dalam hal ini pembangunan kontruksi di daerah Kabupaten Indragiri
Hilir khusus di daerah hilir banyak menghasilkan permasalahan terkait geoteknik untuk perlakuan tanah yang tidak memenuhi daya dukung mulai dari bangunan yang miring, bangunan yang tenggelam (turun), bangunan yang berubah posisinya sampai pada kondisi yang tidak aman atau tidak layak huni akibat konstruksinya rusak (pecah dan retak) serta permasalahan lainnya. Tanah Gambut pada umumnya mempunyai daya dukung yang rendah dan memiliki sifat kompresibel tinggi dan permeabilitas yang rendah.Sifat tanah yang memiliki sifat kompresibel tinggi dan permeabilitas yang rendah cenderung memilki potensi penurunan yang besar dan dalam waktu yang lama

Cerocok sebagai altenatif alat pengganti tiang pancang untuk perkuatan tanah lunak banyak digunakan untuk membangun rumah toko sampai 5 lantai namun belum ada evaluasi atau standar yang mendetail tentang penggunaan cerocok ini, sehingga sering ditemui cerocok dipasang dengan jarak atau spasi yang berbeda-beda sesuai dengan pengalaman masing-masing perencana dan praktisi. 


\section{TINJAUAN PUSTAKA}

\section{A. Klasifikasi Tanah}

Sebagian besar sistem klasifikasi tanah didasarkan pada sifat-sifat tanah yang sederhana seperti distribusi ukuran butir dan plastisitas tanah. Sistem klasifikasi memberikan suatu bahasa yang mudah untuk menjelaskan secara singkat sifat-sifat umum tanah yang sangat bervariasi tanpa penjelasan yang terperinci. Menurut DAS M Braja (1988), sebagian besar sistem klasifikasi tanah yang telah dikembangkan untuk tujuan rekayasa didasarkan pada sifat-sifat indeks tanah yang sederhana seperti distribusi ukuran butiran dan plastisitas.

\section{B. Tanah Organik}

Tanah dalam ilmu Mekanika Tanah adalah semua bahan mulai dari lempung sampai kerikil yang merupakan endapan alam dan secara umum memiliki tiga bahan yaitu butiran tanah, air dan udara yang terdapat dalam ruang antara butiran-butiran tanah tersebut. Menurut Das (1995), Tanah merupakan material yang terdiri dari agregat (butiran) mineralmineral padat yang tidak tersementasi (terikat secara kimia) satu sama lain dan dari bahan-bahan organik yang telah melapuk (yang berpartikel padat) disertai dengan zat cair dan gas yang mengisi ruang-ruang kosong diantara partikel-partikel pada tersebut. Berikut ini merupakan penjelasan secara umum dari sifat-sifat teknis berbagai jenis tanah Christady, (2002).

\section{Perkautan Tanah Lunak dengan Cerocok Bakau} Pile raft atau biasa disebut cerucuk sejak dahulu sudah sering digunakan masyarakat untuk keperluan pembangunan rumah, ruko ataupun perkantoran. Cerucuk kayu atau yang dikenal dengan istilah populernya "Cerocok", adalah tiang-tiang kayu yang digunakan sebagai pondasi rumah dan gedung bertingkat di tanah rawa. Ada tiga jenis kayu cerocok yang umumnya dipergunakan di Provinsi Riau yakni, kayu bakau ubar dan mahang. Penggunaan cerucuk bertujuan untuk :

1. Meningkatkan daya dukung tanah

2. Mengurangi terjadinya penurunan pondasi

3. Menghindari terjadinya gelinciran, karena cerucuk dapat menahan gaya geser lebih besar dari pada tanah, selain itu cerucuk merupakan suatu tulangan penguat sehingga akan mampu menahan gerakan-gerakan tersebut.

\section{Metode Cone Penetration Test (CPT)}

Cone Penetration Test (CPT) atau lebih sering disebut sondir adalah salah satu survey lapangan yang berguna untuk memperkirakan letak lapisan tanah keras. Tes ini baik dilakukan pada lapisan tanah lempung. Tes ini didapatkan nilai perlawanan penetrasi konus. Perlawanan penetrasi konus adalah perlawanan tanah terhadap ujung konus yang dinyatakan dalam gaya per satuan luas. Sedangkan hambatan lekat adalah perlawanan geser tanah terhadap selubung bikonus dalam gaya per satuan panjang. Nilai perlawanan penetrasi konus dan hambatan lekat dapat diketahui dari bacaan pada manometer.

\section{E. Pengujian Daya Dukung Pondasi dengan \\ Pembebanan Statis Metode}

Pondasi merupakan struktur terpenting dari suatu bangunan, Pondasi adalah bagian yang tak terpisahkan dari suatu konstruksi yang mana berfungsi untuk meneruskan gaya-gaya maupun beban dari suatu konstruksi ke lapisan tanah yang berada dibawahnya.

Penanaman tiang pondasi selesai dikerjakan, maka perlu dilakukan suatu pengujian pembebanan (loading test) untuk menentukan daya dukung ultimate pondasi langsung di lapangan.Pengujian pembebanan (Loading Test) biasa disebut juga dengan uji pembebanan statik aksial (Static axial Loading Test). Uji beban skala penuh adalah metode yang paling dapat dipercaya tapi memiliki beberapa kekurangan yaitu:

a. membutuhkan biaya yang besar;

b. waktu yang relatif lama;

c. bahaya bagi pekerja karena tumpukan blok-blok beton yang digunakan untuk pengujian (Setio dkk., 2000).

\section{F. Daya Dukung Tiang Berdasarkan Data Sondir}

Kapasitas daya dukung tiang tunggal berdasarkan pada penyajian data hasil sondir maka beban ijin (Pall) bisa dihitung dengan memakai metode - metode sebagai berikut :

a. Metode Mayerhof (1956)

Pult $=\mathrm{qc}_{\mathrm{r}} \cdot \mathrm{A}_{\mathrm{b}}+\Sigma \mathrm{fs} \cdot \mathrm{A}_{\mathrm{s}}$

Dengan,

- Pult = Beban maskimum

- $\mathrm{Ab}=$ Luas dasar penampang pondasi tiang

- As = Panjang keliling pondasi tiang

- $\mathrm{qc}_{\mathrm{r}}=\mathrm{qc}$ rata-rata, sepanjang 4 diamter bagian atas rencana ujung tiang dan 1 diameter dibawah ujung tiang

- FK = Faktor keamanan sebesar 2,5

b. Metode Trafimankove (1974)

$$
\text { Pult }=k b \cdot q c \cdot A+\left(\frac{J H P}{D}\right) Q \text {. }
$$

Dengan,

- Pult = Beban maskimum

- $\mathrm{kb}=$ Resintensi Factor tahanan ujung $(0,75)$

- A = Luas dasar penampang pondasi tiang

- $\mathrm{D}=1,5-3$ 
- JHP = Jumlah hambatan pelekat

- $\mathrm{qc}=$ Tahanan ujung tiang

c. Metode Begemann

$$
\text { Pult }=k b \cdot q c \cdot A+\left(\frac{J H P}{D}\right) Q \text {. }
$$

\section{Dengan,}

- Pult = Beban maskimum

- $\mathrm{q}_{\mathrm{cu}}=\mathrm{qc}$ rata-rata sepanjang 8 diamter bagian atas ujung tiang

- $\mathrm{q}_{\mathrm{cb}}=\mathrm{qc}$ rata-rata sepanjang 3,5 diameter bagian bawah ujung tiang

- $\mathrm{A}=$ Luas dasar penampang pondasi tiang

- JHP= Jumlah hambatan pelekat

- $\mathrm{Q}=$ Panjang keliling pondasi tiang

G. Kapasitas kelompok dan perhitungan efiseinsi kelompok tiang

Kelompok tiang dalam tanah lunak, pasir tidak padat, atau timbunan, dengan dasar tiang yang bertumpu pada lapisan kaku, maka kelompok tiang tersebut tidak mempunyai resiko akan mengalami keruntuhan geser umum (general shear failure), jika diberikan faktor aman yang cukup terhadap bahaya keruntuhan tiang tunggalnya

a. Formula Conversi - Labarre
$\left(e=1-\theta \frac{(n-1) m+(m-1) n}{90 m n}\right) . .$.

Dengan,

- $\mathrm{e}=$ Efesiensi kelompok tiang

- $\theta=\operatorname{arctg} \mathrm{d} / \mathrm{s}$, dalam derajat

- $\mathrm{m}=$ jumlah baris tiang

- $\mathrm{n}=$ jumlah tiang dalam satu baris

- $\mathrm{d}=$ diameter tiang

- $\mathrm{s}=$ jarak pusat ke pusat tiang

b. Formula Los Angeles Kelompok

$\left(e=1-\theta \frac{(n-1) m+(m-1) n}{90 m n}\right)$

Dengan,

- $\mathrm{e}=$ Efesiensi kelompok tiang

- $\theta=\operatorname{arctg} \mathrm{d} / \mathrm{s}$, dalam derajat

- $\mathrm{m}=$ jumlah baris tiang

- $\mathrm{n}=$ jumlah tiang dalam satu baris

- $\mathrm{d}=$ diameter tiang

- $\mathrm{s}=$ jarak pusat ke pusat tiang

c. Efisiensi Kelompok Tiang

$\Sigma Q_{u}=m \cdot n\left(Q_{p}+Q_{s}\right) \cdot e$

Dengan,

- Qp = daya dukung ujung tiang

- Qs = daya dukung selimut tiang

- $\mathrm{e}=$ Efesinesi kelompok tiang

- $\mathrm{m}=$ jumlah baris tiang

- $\mathrm{n}=$ jumlah tiang dalam satu baris

\section{H. Medote Interpretasi Kapasitas Dukung Tekan} Pondasi

Terdapat bebarapa metode yang dapat di gunakan untuk menginterpretasikan daya dukung tekan pondasi dengan menggunakan hasil pengujian pembebanan secara langsung

a) Metode Davisson (1972)

Prosuder penentuan beban ultimit dari pondasi tiang dengan menggunakan metode ini adalah :

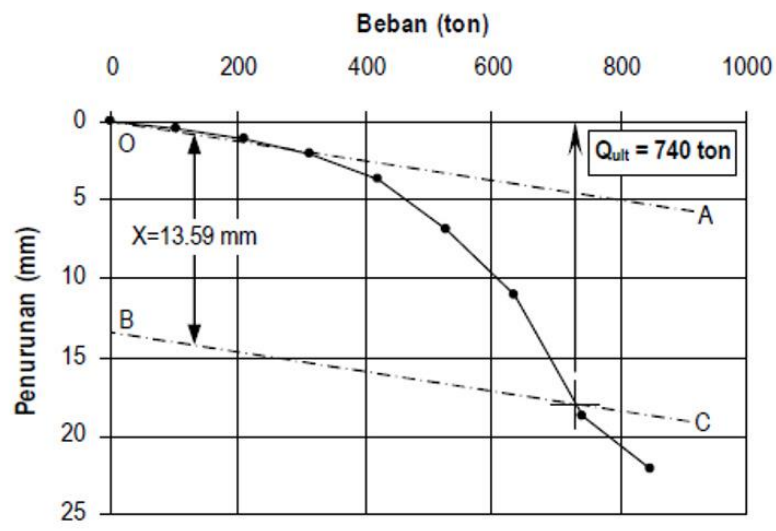

Gambar 2.1 Interpretasi daya dukung dengan metode Davisson

(Sumber : Manual Pondasi Tiang, 2005)

b) Metode Chin F.k (1971)

Metode Chin didasari anggapan bahwa bentuk grafik hubungan pembebanan dengan penurunan adalah hyperbola. Metode ini biasanya menghasilkan Beban Ultimit yang terlalu tinggi, sehingga harus dikoreksi yaitu dengan cara di bagi 1,2 s/d 1,4. (Sumber: Paulus P, 1989.)

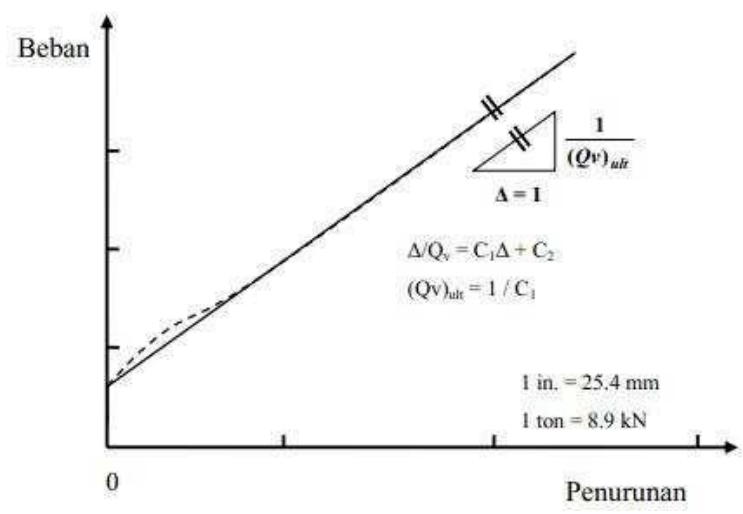

Gambar 2.2.Grafik Hubungan Beban Dengan

Penurunan Menurut Metode Chin

c) Metode Mazurkiewicz (1972)

Metode mazurkiewicz di dasari anggapan bahwa bentuk grafik hubungan pembebabanan dengan penurunan adalah sedemikian rupa sehingga jika di lakukan manipulasi gambar dapat ditentukan daya dukung ultimitnya 


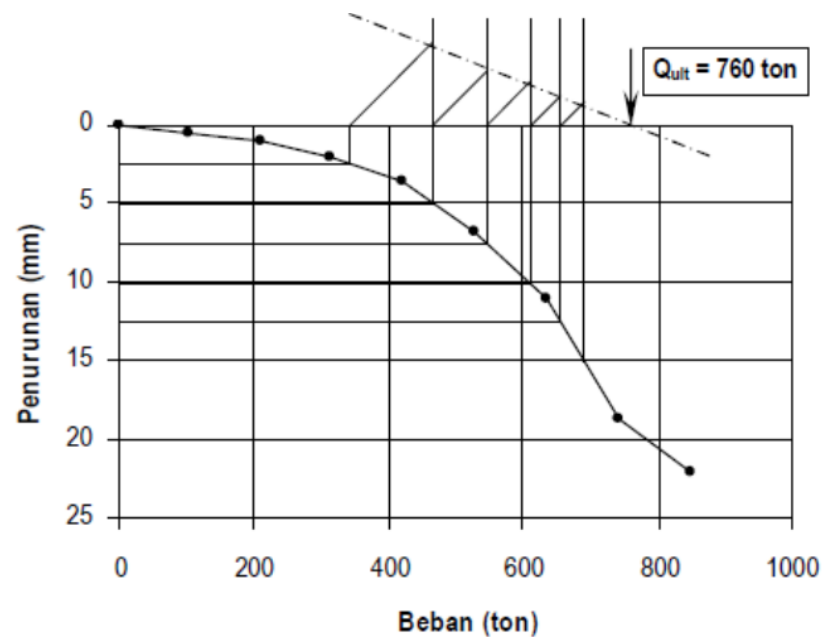

Gambar 2.3. Interpretasi daya dukung ultimit dengan Metode Mazurkiewicz

(Sumber : Manual Pondasi Tiang,2005)

\section{METODOLOGI PENELITIAN}

Pengujian yang dilakukan meliputi Pengambilan data sondir sebanyak 2 titik sampai kedalaman $20 \mathrm{~m}$, pengujian sifat mekanis tanah gambut berupa kuat geser. Pengujian sifat fisis, meliputi berat jenis, kadar air, berat volume, angka pori, kadar serat, kadar abu dan kadar organik pada penelitian sebelumnya sudah diuji

Penelitian dilakukan di jalan sungai beringin Kelurahan Sungai Beringin Kecamatan Tembilahan Kabupaten Indragiri Hilir Provinsi Riau. Pengujian dilakukan dengan skala penuh di lapangan, dengan beban cerocok tunggal $50 \mathrm{~kg} / 25 \%$, sebanyak $200 \%$, cerocok kelompk menggunakan beban beton bertulang $1,2 \mathrm{~m} \times 0,6 \mathrm{~m} \times 0,15 \mathrm{~m}$.

\section{Bahan Penelitian}

Bahan yang digunakan dalam penelitian ini antara lain;

Cerocok panjang $\pm 7 \mathrm{~m}$ dengan diameter pangkal $9 \mathrm{~cm}$ dan ujung $5 \mathrm{~cm}$

Dail gauge untuk pembacaan penurunan

\section{Benda Uji}

Benda uji yang dipakai adalah cerucuk bakau yang kemudian tanam kedalam tanah sepanjang 6,8 m. Jumlah pengujian pembebanan 1 kali dengan 1 jenis kayu cerucuk yakni bakau dengan diameter $9 \mathrm{~cm}$ dengan kondisi sebenarnya di lapangan. Untuk tiang cerucuk kelompok dibuat dengan kelompok persegi $2 \times 2$ dengan variasi spasi atau jarak rapat $2,5 \mathrm{~d}$ dan 3 d. Pengujian kuat tekan dilakukan dengan metode loading test dengan pembebanan $50 \mathrm{~kg}$ per interpal untuk cerocok tunggal dan $150 \mathrm{~kg}$ untuk cerocok kelompok spasi 0d, 2,5D dan 3D.

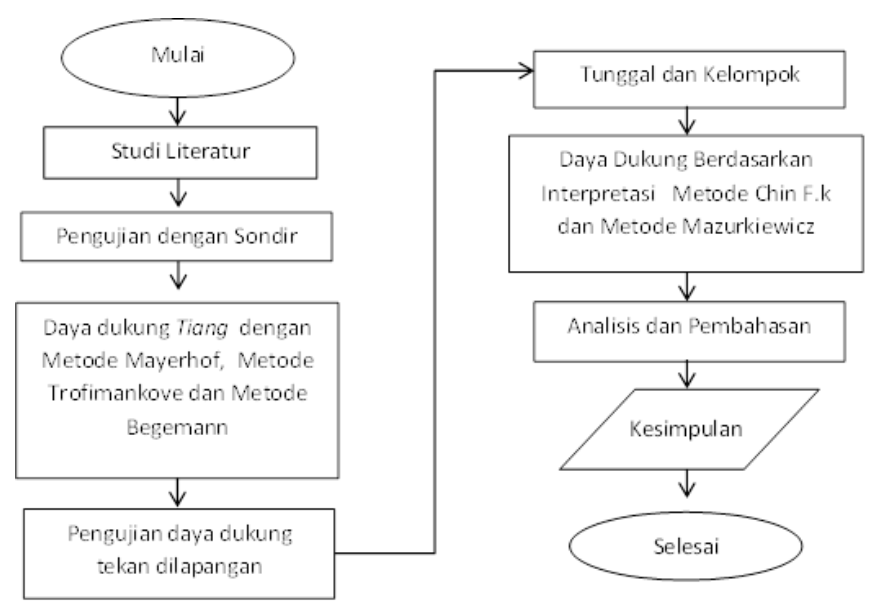

Gambar 3. Diagram Alir Penelitian

\section{HASIL DAN PEMBAHASAN}

\section{A. Perhitungan Kapasitas Aksial Pondasi Cerucuk}

\section{a. Cerocok Tunggal}

Daya dukung aksial pondasi yang dipancangkan berdasarkan hasil pengujian sondor pada suatu tanah gambut dihitung dengan metode Mayerhof, metode Trofimankove dan metode Begemann

Besarnya nilai daya dukung aksial pondasi tiang tunggal dihitung dengan langkah-langkah sebagai berikut :

Data-data model tiang sebagai berikut :

- Diameter Tiang Atas D = $90 \mathrm{~mm}=0,09 \mathrm{~m}$

- Diameter Tiang Bawah D=50 mm

- Panjang Tiang tertanam $=\mathrm{L}=680 \mathrm{~cm}$

- Asumsi Diameter $=(9+5) / 2=14 / 2=7 \mathrm{~cm}$

- Qc (tahanan ujung tiang) $=3 \mathrm{~kg} / \mathrm{cm}^{2}$

- HP (jumlah hambatan pelekat) $\mathrm{H}: 6,8 \mathrm{~m}=30 \mathrm{~kg} / \mathrm{cm}$

- $A=\pi r^{2}=3,14 \times 3,5^{2}=38,46 \mathrm{~cm}^{2}$

- $K=\pi \mathrm{D}=3,14 \times 7=21,98 \mathrm{~cm}$

Tabel 4.1 Daya dukung ultimit Cerocok bakau tunggal

\begin{tabular}{cc} 
Metode & Qultimit \\
\hline Mayerhof & $774,78,02 \mathrm{~kg}$ \\
Trofimankove & $416,25 \mathrm{~kg}$ \\
Begemann & $718,06 \mathrm{~kg}$ \\
\hline
\end{tabular}

b. Cerocok Bakau Kelompok 0D

Perhitungan efisiensi kelompok tiang dengan Formula Converse - Labarre dihitung dengan rumus berikut :

$$
\begin{aligned}
e & =1-\theta\left[\frac{(n-1) m+(m-1) n}{90 \times m \times n}\right] \\
\theta & =\arctan (\mathrm{D} / \mathrm{s}) \\
\theta & =\arctan (0,09 / 0,09) \\
& =45 \\
e & =1-45\left[\frac{(2-1) 2+(2-1) 2}{90 \times 2 \times 2}\right] \\
e & =1-0,5 \\
e & =0,5
\end{aligned}
$$


Perhitungan efisiensi kelompok tiang dengan Formula Los Angeles Kelompok dihitung dengan rumus berikut :

$$
\begin{aligned}
& e=1-\frac{d}{\pi \times S \times m}[m(n-1)+(m-1)+\sqrt{2(m-1)(n-1)}] \\
& e=1-\frac{9}{3,14 \times 9 \times 2}[2(2-1)+(2-1)+\sqrt{2(2-1)(2-1)}] \\
& e=1-0,70 \\
& e=0,30
\end{aligned}
$$

Tabel 4.2 Daya dukung ultimit efesiensi Kelompok tiang 0D

\begin{tabular}{ccc}
\hline & Converse - \\
Metode & Labarre & Los Angeles \\
\hline Mayerhof & $1549,56 \mathrm{~kg}$ & $929,73 \mathrm{~kg}$ \\
Trofimankove & $832,49 \mathrm{~kg}$ & $499,49 \mathrm{~kg}$ \\
Begemann & $1436,12 \mathrm{~kg}$ & $861,67 \mathrm{~kg}$ \\
\hline
\end{tabular}

c. Cerocok Bakau Kelompok 2,5D

$>$ Perhitungan efisiensi kelompok tiang dengan Formula Converse - Labarre dihitung dengan rumus berikut :

$$
\begin{aligned}
e & =1-\theta\left[\frac{(n-1) m+(m-1) n}{90 \times m \times n}\right] \\
\theta & =\arctan (\mathrm{D} / \mathrm{s}) \\
\theta & =\arctan (0,09 / 0,225) \\
& =21,80 \\
e & =1-21,80\left[\frac{(2-1) 2+(2-1) 2}{90 \times 2 \times 2}\right] \\
e & =1-0,24 \\
e & =0,76
\end{aligned}
$$

> Perhitungan efisiensi kelompok tiang dengan Formula Los Angeles Kelompok dihitung dengan rumus berikut :

$$
\begin{aligned}
& e=1-\frac{d}{\pi \times S \times m}[m(n-1)+(m-1)+\sqrt{2(m-1)(n-1)}] \\
& e=1-\frac{9}{3,14 \times 22,5 \times 2}[2(2-1)+(2-1)+\sqrt{2(2-1)(2-1)}] \\
& e=1-0,28 \\
& e=0,72
\end{aligned}
$$

Tabel 4.3 Daya dukung ultimit efesiensi Kelompok tiang 2,5D

\begin{tabular}{ccc}
\hline & Converse - & \\
Metode & Labarre & Los Angeles \\
\hline Mayerhof & $2355,33 \mathrm{~kg}$ & $2231,36 \mathrm{~kg}$ \\
Trofimankove & $1265,38 \mathrm{~kg}$ & $1198,78 \mathrm{~kg}$ \\
Begemann & $2182,90 \mathrm{~kg}$ & $2068,02 \mathrm{~kg}$ \\
\hline
\end{tabular}

d. Cerocok Bakau Kelompok 3D

$>$ Perhitungan efisiensi kelompok tiang dengan Formula Converse - Labarre dihitung dengan rumus berikut :

$$
\begin{aligned}
e & =1-\theta\left[\frac{(n-1) m+(m-1) n}{90 \times m \times n}\right] \\
\theta & =\arctan (\mathrm{D} / \mathrm{s}) \\
\theta & =\arctan (0,09 / 0,27) \\
& =18,43 \\
e & =1-18,43\left[\frac{(2-1) 2+(2-1) 2}{90 \times 2 \times 2}\right] \\
e & =1-0,20 \\
e & =0,80
\end{aligned}
$$

$>$ Perhitungan efisiensi kelompok tiang dengan Formula Los Angeles Kelompok dihitung dengan rumus berikut :

$$
\begin{aligned}
& e=1-\frac{d}{\pi \times S \times m}[m(n-1)+(m-1)+\sqrt{2(m-1)(n-1)}] \\
& e=1-\frac{9}{3,14 \times 27 \times 2}[2(2-1)+(2-1)+\sqrt{2(2-1)(2-1)}] \\
& e=1-0,23 \\
& e=0,76
\end{aligned}
$$

q ultimit efisiensi tiang untuk Formula Los Angeles dengan metode Mayerhof adalah yakni sebesar $2201,02 \mathrm{~kg}$, metode Trofimankove adalah yakni sebesar $1265,38 \mathrm{Kg}$ dan metode Begemann adalah yakni sebesar $2147,23 \mathrm{Kg}$. ada perbedaan q ultimit pada 3 (tiga) metode, seperti pada tabel 4.4

Tabel 4.4 Daya dukung ultimit efesiensi Kelompok tiang 3D

\begin{tabular}{ccc}
\hline Metode & Converse - Labarre & Los Angeles \\
\hline Mayerhof & $2479,29 \mathrm{~kg}$ & $2355,33 \mathrm{~kg}$ \\
Trofimankove & $1331,99 \mathrm{~kg}$ & $1265,38 \mathrm{~kg}$ \\
Begemann & $2297,79 \mathrm{~kg}$ & $2182,90 \mathrm{~kg}$ \\
\hline
\end{tabular}

\section{B. Pengujian permodelan Cerucuk}

\section{a. Pengujian Cerocok Model Tunggal}

Hasil dari pengujian model pondasi cerocok bakau tunggal yang dilakukan di tunjukan dalam grafik yang berhubungan dengan gaya dan penurunan yang terjadi yang terlihat pada gambar 4.1 di bawah ini

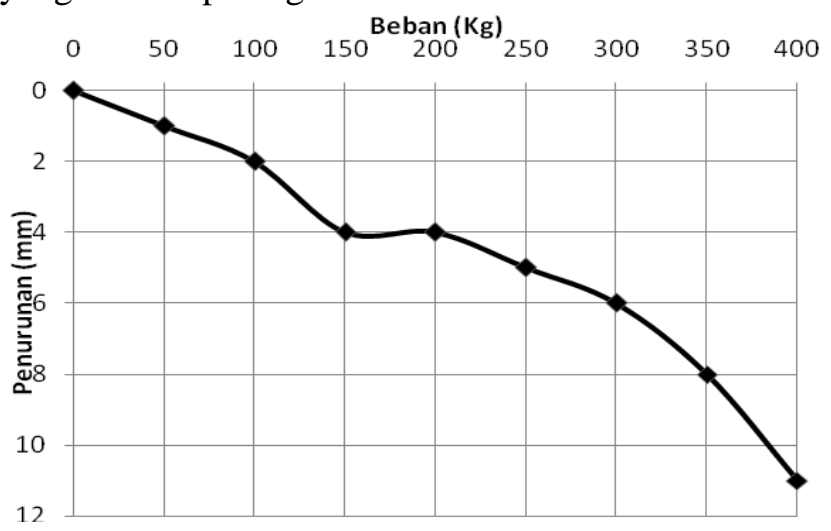

Gambar 4.1 Grafik hasil pengujian model cerocok tunggal 
b. Pengujian Model Cerocok Kelompok Spasi OD

Hasil dari pengujian model pondasi cerocok kelompok spasi Od yang dilakukan di tunjukan dalam gambar grafik yang berhubungan dengan gaya dan penurunan yang terjadi yang terlihat pada gambar 4.2:

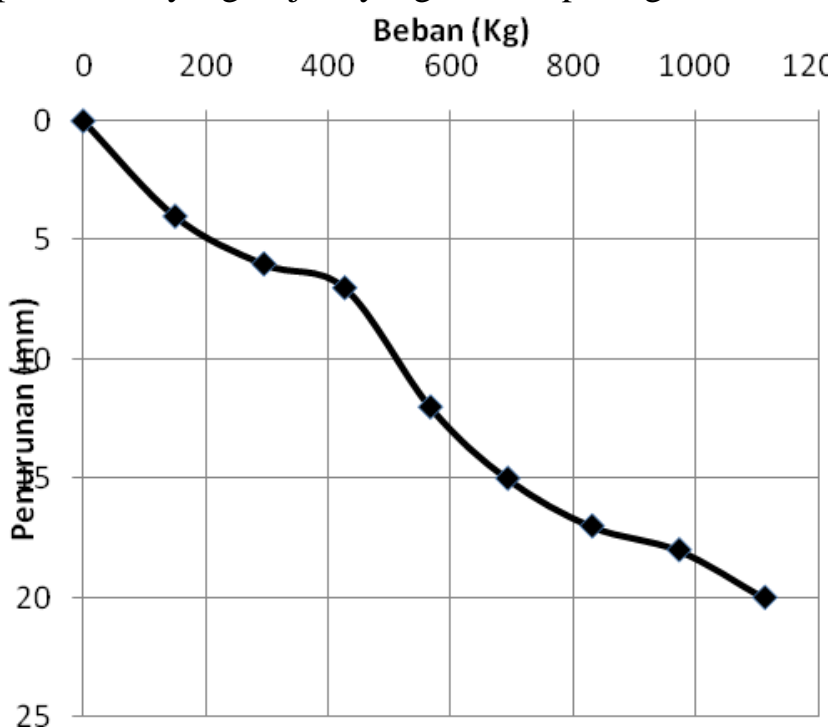

Gambar 4.2 Grafik hasil pengujian model cerocok kelompok spasi 0D

c. Pengujian Model Cerocok Kelompok Spasi $2,5 \mathrm{D}$

Hasil dari pengujian model pondasi cerocok kelompok spasi 2,5d yang dilakukan di tunjukan dalam gambar grafik yang berhubungan dengan gaya dan penurunan yang terjadi yang terlihat pada gambar 4.3:

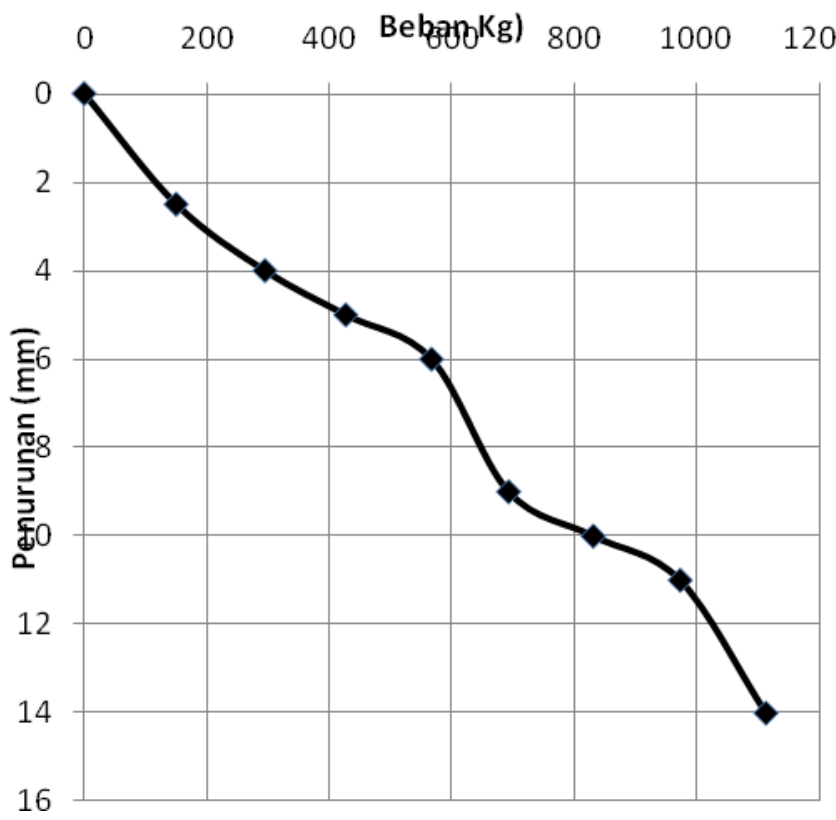

Gambar 4.3 Grafik hasil pengujian model cerocok kelompok spasi 2,5D

\section{d. Pengujian Model Cerocok Kelompok Spasi 3D}

Hasil dari pengujian model pondasi cerocok kelompok spasi 3d yang dilakukan di tunjukan dalam gambar grafik yang berhubungan dengan gaya dan penurunan yang terjadi yang terlihat pada gambar 4.4:

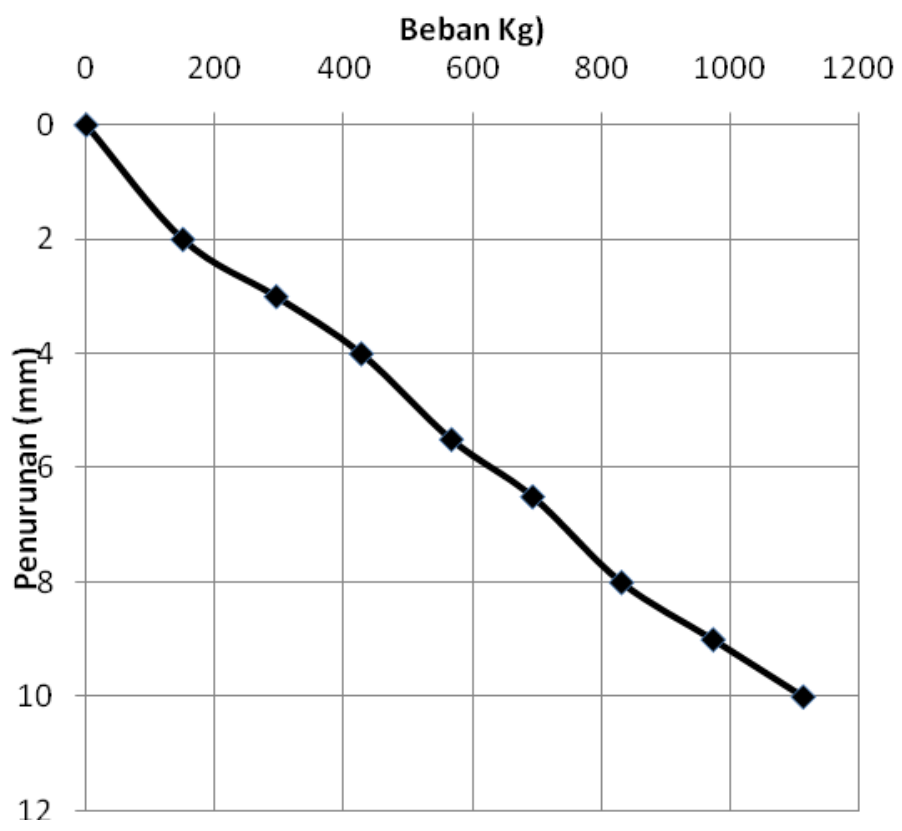

Gambar 4.4 Grafik hasil pengujian model cerocok kelompok spasi 3D

\section{Interpretasi Metode Chin}

Metode Chin didasari anggapan bahwa bentuk grafik hubungan pembebanan dengan penurunan adalah hyperbola. Meskipun uji beban belum dilakukan hingga batas beban kegagalan, dengan anggapan grafik tersebut, maka beban kegagalan dapat di perkirakan

a) Cerocok Tunggal

Penurunan maksimal yang terjadi pada cerocok bakau tunggal adalah mencapai penurunan 11 $\mathrm{mm}$ dengan beban maksimal yang di berikan sebesar $400 \mathrm{Kg}$.

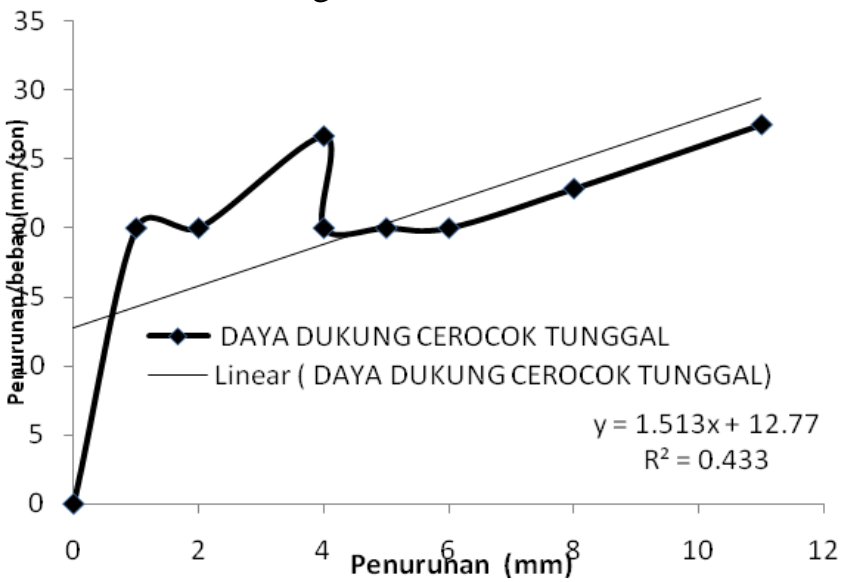

Gambar 4.4 Interpretasi Qu metode Chin Cerocok Tunggal 
b) Cerocok Bakau Kelompok 0D

Penurunan maksimal yang terjadi pada cerocok bakau tunggal adalah mencapai penurunan 20 mm dengan beban maksimal yang di berikan sebesar $1113 \mathrm{Kg}$.

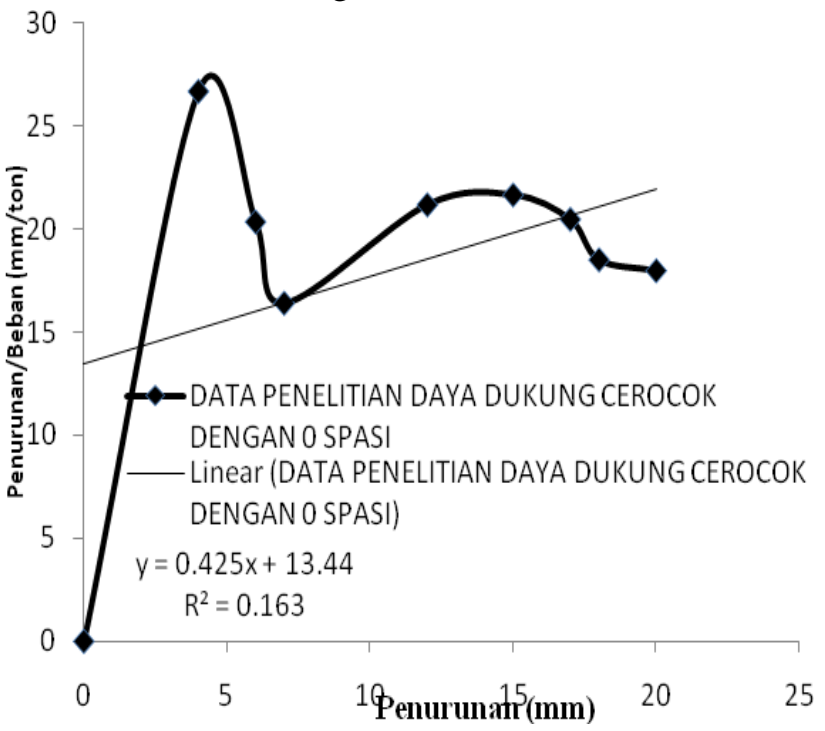

Gambar 4.5 Interpretasi Qu metode Chin Cerocok Kelompok Spasi 0D

c) Cerocok Bakau Kelompok 2,5D

Penurunan maksimal yang terjadi pada cerocok bakau tunggal adalah mencapai penurunan 14 $\mathrm{mm}$ dengan beban maksimal yang di berikan sebesar $1113 \mathrm{Kg}$.

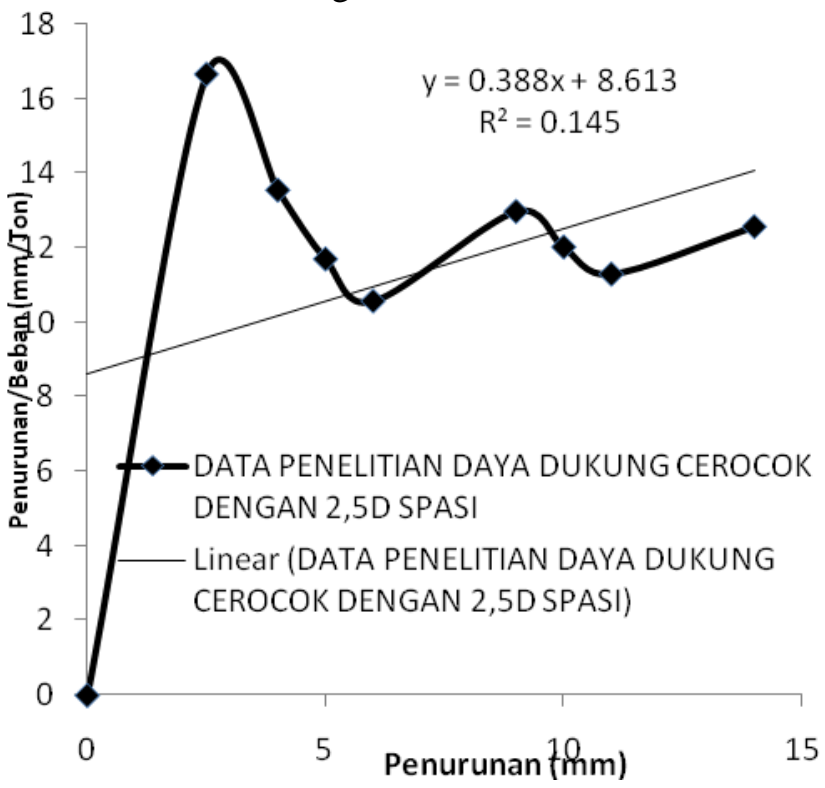

Gambar 4.6 Interpretasi Qu metode Chin Cerocok Kelompok Spasi 2,5D

d) Cerocok Bakau Kelompok 3D

Penurunan maksimal yang terjadi pada cerocok bakau tunggal adalah mencapai penurunan 10 $\mathrm{mm}$ dengan beban maksimal yang di berikan sebesar $1113 \mathrm{Kg}$.
Vol.4.No.lua620

JUTI-UNISI (Jurnal Teknik Industri Unisi )

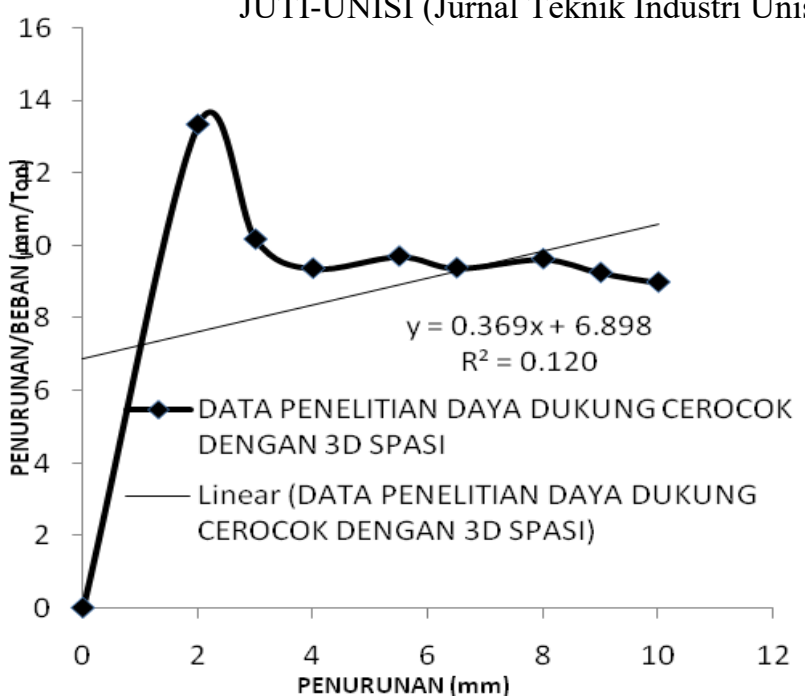

Gambar 4.7 Interpretasi Qu metode Chin Cerocok Kelompok Spasi 3D

$$
\begin{aligned}
\mathrm{Qu} & =1 / \mathrm{C} 1 \\
\mathrm{Qu} & =1 / 0,369 \\
& =2,710 \mathrm{Ton} \\
& =2710 \mathrm{Kg} / 1,4 \\
& =1935,71 \mathrm{Kg}
\end{aligned}
$$

D. Interpretasi Meode Mazurkiewicz

Metode mazurkiewicz di dasari anggapan bahwa bentuk grafik hubungan pembebabanan dengan penurunan adalah sedemikian rupa sehingga jika di lakukan manipulasi gambar dapat ditentukan daya dukung ultimitnya

a) Cerocok Tunggal

Berdasarkan gambar 4.8 tersebut terdapat 6 garis yang berpotong di antaranya beban yang searah sumbu tiang untuk di hubungkan beban dengan titik - titik dari posisi garis terhadap sudut $45^{\circ}$ pada sumbu beban yang berbatasan dengan beban sehingga di hasilkan $Q$ ultimit untuk cerocok bakau tunggal adalah sebesar $447 \mathrm{~kg}$.

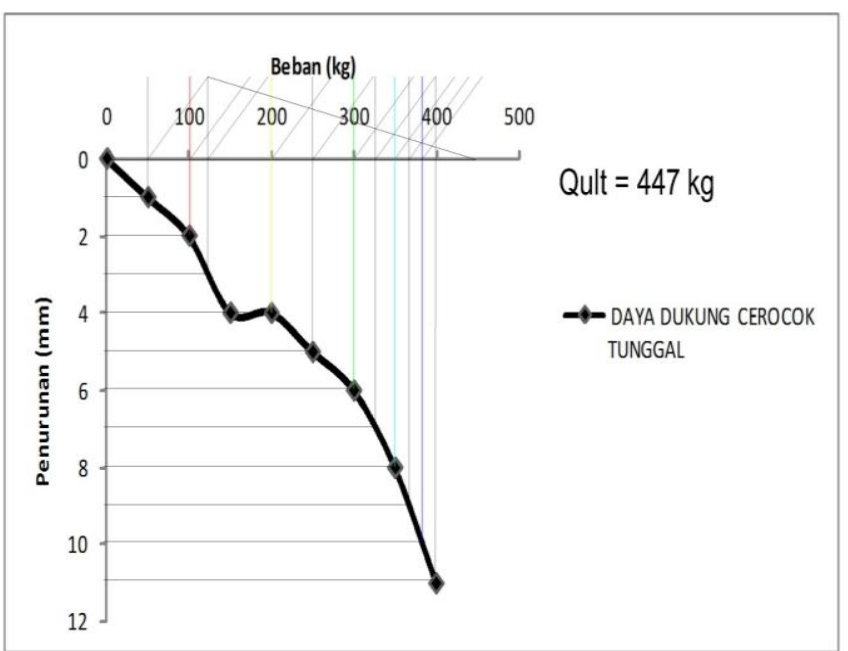

Gambar 4.8 Grafik Interpretasi Qult untuk cerocok bakau tunggal 
b) Cerocok Bakau Kelompok 0D

Berdasarkan gambar 4.9 tersebut terdapat 3 garis yang berpotong di antaranya beban yang searah sumbu tiang untuk di hubungkan beban dengan titik - titik dari posisi garis terhadap sudut $45^{\circ}$ pada sumbu beban yang berbatasan dengan beban sehingga di hasilkan $Q$ ultimit untuk cerocok bakau tunggal adalah sebesar $1211 \mathrm{~kg}$.

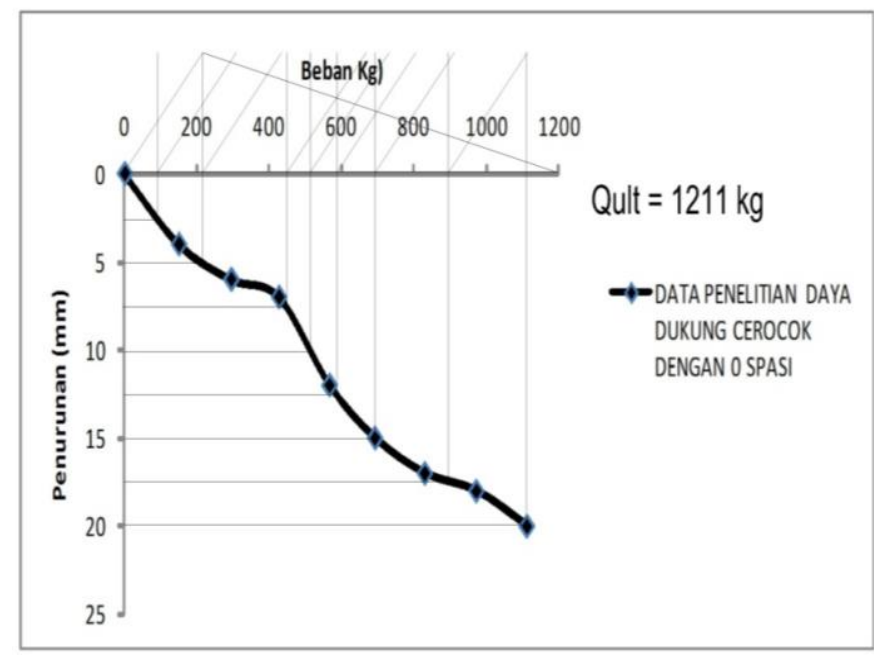

Gambar 4.9 Grafik Interpretasi Qult untuk cerocok bakau Kelompok Spasi OD

c) Cerocok Bakau Kelompok 2,5D

Berdasarkan gambar 4.10 tersebut terdapat 4 garis yang berpotong di antaranya beban yang searah sumbu tiang untuk di hubungkan beban dengan titik - titik dari posisi garis terhadap sudut $45^{\circ}$ pada sumbu beban yang berbatasan dengan beban sehingga di hasilkan Q ultimit untuk cerocok bakau tunggal adalah sebesar $1903 \mathrm{~kg}$

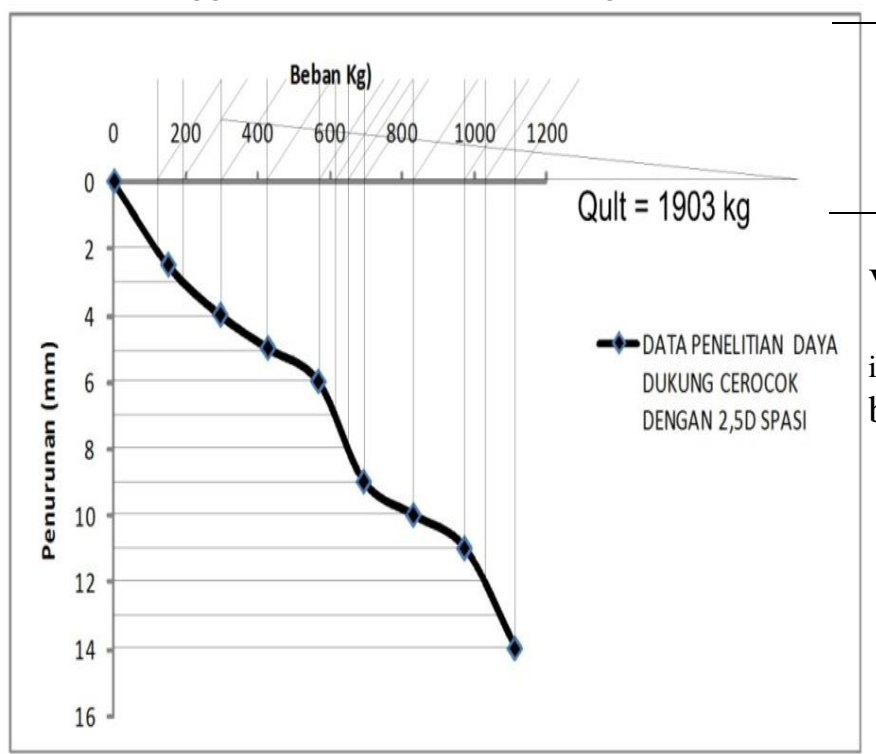

Gambar 4.10 Grafik Interpretasi Qult untuk cerocok bakau Kelompok Spasi 2.5D

d) Cerocok Bakau Kelompok 3D

Berdasarkan gambar 4.11 tersebut terdapat 5 garis yang berpotong di antaranya beban yang searah sumbu tiang untuk di hubungkan beban dengan titik - titik dari posisi garis terhadap sudut $45^{\circ}$ pada sumbu beban yang berbatasan dengan beban sehingga di hasilkan $Q$ ultimit untuk cerocok bakau tunggal adalah sebesar $2010 \mathrm{~kg}$.

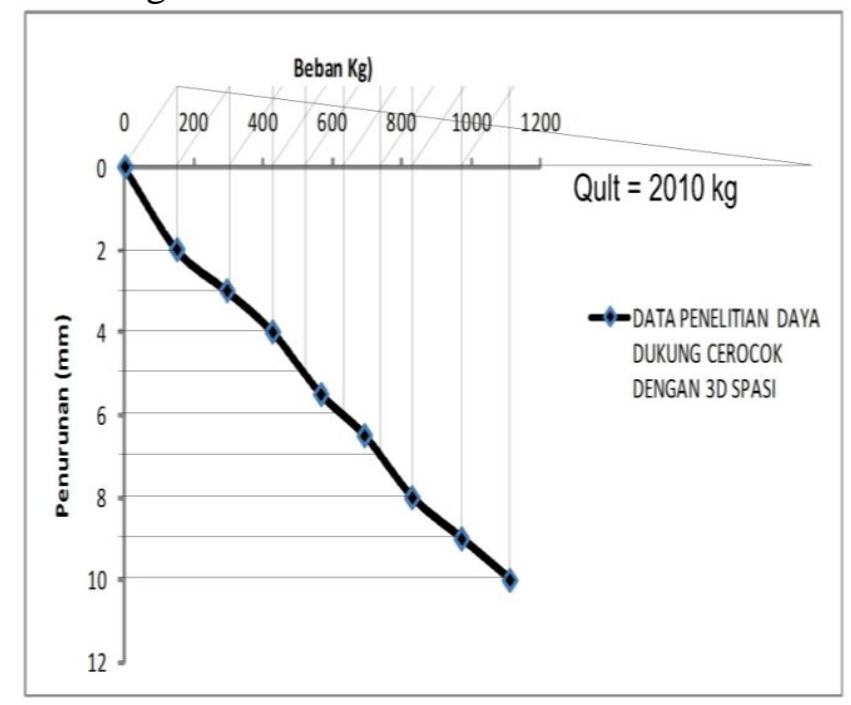

Gambar 4.11 grafik Interpretasi Qult untuk cerocok bakau Kelompok Spasi 3D

Q ultimit pengujian cerocok bakau dengan metode interpretasi Mazurkiewicz dan Chin method, seperti pada tabel 4.4

Tabel 4.16 Nilai Q ultimit Pengujian Cerocok Bakau metode Interpretasi.

\begin{tabular}{lcc}
\hline \multicolumn{1}{c}{ Data } & $\begin{array}{c}\text { Mazurkiewicz } \\
\text { Methode }(\mathrm{Kg})\end{array}$ & $\begin{array}{c}\text { Chins Methode } \\
(\mathrm{Kg})\end{array}$ \\
\hline Tunggal & 447 & 472 \\
Kelompok 0D & 1211 & 1680 \\
Kelompok 2,5D & 1903 & 1840 \\
Kelompok 3D & 2010 & 1935 \\
\hline \multicolumn{3}{|}{} \\
V. KESIMPULAN \\
Berdasarkan hasil penelitian dan analisis dalam penelitian \\
ini, maka dapat diambil beberapa kesimpulan sebagai \\
berikut:
\end{tabular}

1. Daya dukung ultimate Cerucuk tunggal dengan panjang $7 \mathrm{~m}$ berdasarkan data sondir dengan Metode Mayerhoff sebesar 774,78,02 kg, Metode Begemann sebesar 416,25 kg, Metode Trofimankove sebesar 718,06 kg, Metode Chin sebesar $472 \mathrm{~kg}$, Metode Mazurkiewicz sebesar $447 \mathrm{~kg}$

2. Berdasarkan perhitungan metode analisis cerucuk tunggal dengan 3 metode (Metode Mayerhoff, Metode Trofimankove dan Metode Begemann), mempunyai rata-rata daya dukung Qultimit $615 \mathrm{~kg}$ dan untuk cerucuk kelompok 0d Qultimit 984,84 kg, cerucuk kelompok 2,5d 
Qultimit 1821, $96 \mathrm{~kg}$ dan cerucuk kelompok 3d Qultimit 1920,45 kg.

3. Berdasarkan perhitungan metode interpretasi cerucuk tunggal dengan 2 metode (metode Chin Fk dan metode Mazurkiewicz), mempunyai ratarata daya dukung Qultimit 459,5 $\mathrm{kg}$ dan untuk cerucuk kelompok 0d Qultimit 1445,5 kg, cerucuk kelompok 2,5d Qultimit 1871,85 kg dan cerucuk kelompok 3d Qultimit 1972,85 kg.

4. Hasil perhitungan dengan metode analis dan interpretasi di ketahui daya dukung ultimit cerucuk permodelan $3 \mathrm{~d}$ lebih besar di bandingkan dengan $0 \mathrm{~d}$ dan $2,5 \mathrm{~d}$

\section{Saran}

Saran yang dapat diberikan untuk penelitian selanjutnya adalah sebagai berikut:

1. Perlu dilakukan pengujian cerocok bakau pada tanah lunak dengan posisi variasi bentuk yang lain, posisi kayu miring atau posisi pola yang lain dan variasi diameter, variasi kedalaman dan efek waktu dalam pembebanan.

2. Jarak antar tiang dalam pengujian sebaiknya sejauh mungkin, untuk menghindari terjadinya pengaruh antar tiang yang dipancangkan.

\section{Daftar Pustaka}

Abdul Hadi, Tesis, Studi Daya Dukung Pondasi Tiang Cerucuk Pada Model Berskala Kecil, Mapibu Teknik Sipil ITB, Bandung, 1990.

Anonim, 1971. Peraturan Konstruksi Kayu Indonesia, PKKI 1961, Penerbit Departemen Pekerjaan Umum, Direktorat Jenderal Cipta Karya, Direktorat Penyelidikan Masalah Bangunan, Bandung.

ASTM D 2607-69., 1989, "Classification of peats, mosses, humus, and related products"

ASTM D4427-92. 2002. Standard Classification of Peat Samples by Laboratory Testing. International Journal of the Physical Sciences. United States of America: Annual Book of ASTM Standards sec 4.

ASTM D1997-91. 2001. Standard Test Method For Laboratory Determination of The Fiber Content of Peat Samples by Dry Mass. United States of America: Annual Book of ASTM Standards sec 4

Bachtiar dan Yusuf. 2008. Pengaruh Variasi Jumlah Cerucuk pada Pondasi Plat Beton Bercerucuk, Jurnal Teknik Sipil UNTAN, Vol. 8 No. 1, Juni 2008

Becker, G. 1975. Termites and Fungi. Organismen Und Holz Internasional Simposium. Dalhem Berlin.
Bowles, J.E., 1991. Analisis dan Desain Pondasi, Edisi keempat Jilid 1, Erlangga, Jakarta

Da Costa EWB, Rudman P, \& Gay FJ. 1958. Investigations on the durability of Tectonagrandis. Empire Forestry Review 37, 291-298

Das, B.M., 1988. Mekanika Tanah (Prinsip Prinsip Rekayasa Geoteknis). Edisi Kesatu. Jakarta :Penerbit Erlangga.

Das, B.M, 1994, Mekanika Tanah (Prinsip-prinsip Rekayasa Geoteknis), Penerbit Erlangga, Jakarta.

Dumanauw, 1990. Faktor Perusak Kayu. Available at : $\quad$ http://library.um.ac.id/freecontents/index.php/buku/detail/mengenalkayu-j-f-dumanauw-17175.html ( Accesed Januari 2015 )

Dumanauw, J.F. 2001. Mengenal Kayu. Yogyakarta: Kanisius

Harimurti, 2008. “ Alternatif Perkuatan Tanah Lempung Lunak ( Soft Clay) menggunakan cerucuk dengan Variasi Panjang dan Diameter Cerucuk. Jalan Mayjen Haryono. 147. Malang

Hary Christady Hardiyatmo, 2002, MEKANIKA TANAH I, Gadjah Mada University Press, Jogjakarta

Hermawan, R., Surjandari, N., dan Saad, S. 2014. Analisis Perkuatan Tanah Dasar Pada Tanggul Sungai Gajah Putih Surakarta dengan Cerucuk Kayu, e-Jurnal Matriks Teknik Sipil, Vol. 2 No. 1 Maret 2014, 147

Iskandar, R., 2002, Beberapa Kendala Teori Perhitungan Daya Dukung Aksial Pondasi Dalam, USU, Sumatra Utara.

Juanda, 2016." Analisis Peningkatan Kapasitas Dukung Tanah dengan Perkuatan Cerocok bakau Tunggal dan Kelompok. Pekanbaru

Kulhawy, F.H., and Trautmann, C.H., 1988. Uplift Load Displacement Behavior Of Spread Foundations. Journal of Geotechnical and Geoenviromental Engineering, ASCE. vo1.114. No.2. pp. 168-184.

Kurniawan, S. dan Muslim. 2008. Fakta hutan dan kebakaran Riau 2002-2007. Jaringan Kerja Penyelamat Hutan Riau. 16 hal

Lutenegger, A. J., \& Adams, M. T. (1998). Bearing Capacity of Footings on Compacted Sand.

Manual Pondasi Tiang (2005). Geotecnical Engineering Center. Unpar.

M. Das, Braja. 1985, "Mekanika Tanah (PrinsipPrinsip Rekayasa Geoteknis)”. Alih Bahasa Mochtar dan Endah, Jakarta: Erlangga.

M. Das, Braja. 1988, "Mekanika Tanah (PrinsipPrinsip Rekayasa Geoteknis)”. Alih Bahasa Mochtar dan Endah, 2009. Jakarta: Erlangga. 
M. Das, Braja. 1998, "Advanced Soil Mechanics ( Second Edition) " USA : Thomson

M. Das, Braja. 2009, "Principles of Foundation Engineering (Sixth Edition)" USA : Thomson.

Mac Farlane, 1959. Muskeq Engineering Handbook "National Reseach Council of Canada" University of Toronto Press, Canada

Muhrozi, 2009, Laporan Hasil Penyelidikan Tanah di lokasi Sta 6+369 Ruas Jalan SemarangBawen, Proyek Pembangunan Jalan Tol Semarang-Solo, Semarang

Putra, H.G., Hakam, A., dan Yusri, N. 2009. Peningkatan Kekuatan Geser Tanah dengan Menggunakan Cerucuk, Jurnal Rekayasa Sipil, Vol. 5 No. 2, Oktober 2009

Roberts, L. A., Misra, A., and Leverson, S. (2008). Practical Method for Load and Resistance Factor Design (LRFD) of Deep Foundations at the Strength and Service Limit States. International Journal of Geotechnical Engineering, 2(4), 355-368.

Roeseno, 1998. Penggunaan Cerucuk Bambu pada Tanah Lunak, Yogyakarta. UGM Press

Sardjono, HS., 1991. Pondasi Tiang Pancang, Jilid 1, Penerbit Sinar Jaya Wijaya, Surabaya.

Setio, HD, Setio, S, Martha,D, Kamal, B.r dan Nasution, S (2000), "Analisis Daya Dukung Tiang Pancang dengan Metode Dinamik", Prosiding Pertemuan Ilmiah Tahunan IV, INDO-GEO 2000 HATTI, Jakarta, V 27 V 35.

Dona - Haryo K (2013) Studi Pengaruh Jarak Tiang Pancang Pada Kelompok Tiang,

Sukirman nurdin, 2011. Analisis Perubahan Kadar Air dan Kuat Geser Tanah Gambut Lalombi Akibat Pengaruh Temperatur dan Waktu Pemanasan, SMARTek, - jurnal.untad.ac.id

Sumarni, Sri. 2007. StrukturKayu. Edisi 1. Surakarta. UNS Press

Suroso, Harimurti dan Harsono, M. (2008). Alternatif Perkuatan Tanah Lempung Lunak (Soft Clay), Menggunakan Cerucuk dengan Variasi Panjang dan Diameter Cerucuk, Jurnal Rekayasa Sipil, Volume 2, No. 1 2008 ISSN 1978 - 5658.

Tarumingkeng,R.C, 2007. Status Pengawetan Kayu di Indonesia http://tumotou.net/702 05123/rudi.htm $\quad\{6$ November 2007\}

Terzaghi, Karl dan Peck 1987. Mekanika Tanah Dalam Praktek Rekayasa Jilid I Edisi Kedua. Jakarta: Erlangga

Tjandrawibawa S., Efendy J., Gunawan W. 2000. Peningkatan Daya Dukung Pondasi Dangkal dengan Menggunakan Cerucuk
(Suatu Studi Model). Jurnal Dimensi Teknik Sipil Vol.2 No.2 ISSN 1410-9530. Surabaya

Van De Meene, 1982, Geological Aspects of Peat Formation in The Indonesian- Malaysian Lowlands, Bulletin Geological Research and Development Centre, Bandung. 